\title{
A Socialised Conceptualisation of Individual Privacy: A Theoretical and Empirical Study of the Notion of the 'Public' in UK MoPI Cases
}

\begin{abstract}
This article seeks to conceptualise a more public, a more socialised notion of privacy in contrast to the archetype: that my privacy is of interest and of value only to me. Doing so has historically left a claim to privacy rather exposed against claims to free speech, with the latter's long pedigree and generally acknowledged wider instrumental role. This article provides a corrective. In the first part, it offers a typology of rationales at one of two meta-levels: privacy as a means to effect assurance or privacy as a means to protect someone's activities. The second discusses the results of some small-scale empirical doctrinal research: a sample analysis of 27 UK privacy cases looking to identify the judicial ascription of the value of privacy, specifically trying to discover whether there was any judicial conceptualising of privacy as having a more social, or public, value or utility. The results are perhaps not unexpected. Almost exclusively, judges frame their rationales for protecting privacy in purely individualised terms.
\end{abstract}

\section{INTRODUCTION}

The mantra of hi-tech company The Circle, in Dave Eggars' novel of the same name, is that

\author{
Secrets are Lies \\ Sharing is Caring \\ Privacy is Theft ${ }^{1}$
}

This emerges out of a staged $Q$ \& A led by one of its founders as part of a public relations exercise seeking to reclaim the democratic value of transparency: lawmakers and officials who have something to hide - that is, lawmakers and officials who refuse to wear The Circle's all-seeing SeeChange camera that offers constant public surveillance of their activities - are suspicious. A little later there is a serious suggestion that all citizens be required to have a Circle account -

David Mead, Professor of UK Human Rights Law, UEA Law School. Address for correspondence: Law School, Earlham Hall, University of East Anglia, Norwich NR4 7TJ d.mead@uea.ac.uk. Thanks to all those who have read or heard the paper before: the SLS Media section, Oxford 2017; UEA faculty seminar; Dr Karen Mc Cullagh and Dr Paul Wragg and the anonymous referee. All errors and views mine.

${ }^{1}$ D Eggars, The Circle (McSweeny's, 2013) 303. 
which includes a voting app - as a means of securing $100 \%$ democratic participation, an obviously Good Thing. Literature has a long history of dystopias along those or similar lines - and some foresee real life following a similar trajectory. Eggars wants us to baulk at these suggestions, and to jolt ourselves awake - we should indeed be wary given the almost imperceptible incrementalism involved in a project such as The Circle's. We do so because we value privacy - our own privacy. We do not see it as serving instrumental goals, even if they might be as socially beneficial as The Circle is trying to claim (but which readers of course doubt).

This article seeks to provide a corrective to both those last contentions. While we each might value our own privacy, and indeed may well value it highly, that leaves claims to an individualised right of privacy rather exposed against claims to a socialised right of free speech, with its long pedigree and generally acknowledged wider instrumental role. This is problematic. It has the effect of setting privacy up to fail, in a battle where the odds are stacked against it. The protection of privacy is generally - or mostly - conceived as an individualised right, of use and value to each of us but not something in which anyone else has any (justifiable) interest. This article therefore considers this simple, alternative question: what interest(s) if any might I have in your privacy?

The article is in three main parts. The first sets out what we might call the traditional debate. It notes the public utility of free speech and the individualised nature of justifications for protecting privacy. The second then offers a typology of rationales that we might pray in aid were we to seek to construct a more socialised notion of privacy, that is privacy with social value or utility. Whilst in general that sites our debate around privacy's common value, using Priscilla Regan's three-fold categorisation ${ }^{2}$, we will also consider elements of what she termed privacy's public value, instrumentally pertaining to the civic, democratic and political sphere (and the opposite of the private realm of family, home and workplace). The last part of this article provides the results of some small-scale

2 P Regan, Legislating Privacy: Technology, Social Values and Public Policy (University of North Carolina Press 1995) 221. 
empirical doctrinal research. ${ }^{3}$ I conducted a sample analysis of 27 UK privacy cases looking to identify the judicial ascription of the value of privacy, specifically trying to discover whether there was any judicial conceptualising of privacy as having a more social, or public, value or utility. ${ }^{4}$ The results are perhaps not unexpected. Almost exclusively, judges frame their rationales for protecting privacy in purely individualised terms.

Before embarking any further, I need to offer some clarifications on terminology and scope. The term 'private life' is not being used in contradistinction to the 'public sphere' 5 , with the former suggesting areas of intimate or personal decision-making, free from governmental (or similar) interference and constraint. ${ }^{6}$ Secondly, the focus of this article is informational privacy, not (in Anita Allen's words) decisional privacy, or 'privacy as autonomy' or 'privacy as seclusion' - the seminal right to be left alone. Even then, the context is media reporting. Digital privacy and state surveillance is outside its parameters save only for any coincidental overlap. Its focus is thus on claims arising from misuse of private information (MOPI): who is able to find out information about me, what information and on what terms? It is what Daniel Solove terms information dissemination, the third of his four harmful activities that implicate privacy. ${ }^{7}$ Lastly, for our purposes, we do not need to avail ourselves of the finer discussions about whether privacy even in this sense is about (in)accessibility (as Ruth Gavison would maintain $^{8}$ ) or about determining control (as Alan Westin argues). ${ }^{9}$

\footnotetext{
${ }^{3}$ To that extent, this builds on and expands the project undertaken by Kirsty Hughes on Article 8 case law more widely and generally at Strasbourg level: see K Hughes, 'The Social Value of Privacy, the Value of Privacy to Society, and Human Rights Discourse' in B Roessler and D Mokrokinska, Social Dimensions of Privacy: Interdisciplinary Perspectives (CUP 2015).

${ }^{4}$ The methodology is set out in more detail on p.xx but in short, a Westlaw search of UK cases, decided between 1 January 1990 and 1 November 2016 (the date of the search), was carried out using two search terms privacy/media (214 cases) narrowed to 45 using privacy /10 media /10 injunction of which $27(60 \%)$ were selected for analysis.

${ }^{5}$ On which the starting point remains J Habermas, The Structural Transformation of the Public Sphere: An Inquiry into a category of Bourgeois Society (MIT Press 1991).

${ }^{6}$ A Allen, 'Taking Liberties: Privacy, Private Choice, And Social Contract Theory' (1987) 56 U Cin L Rev 461, 463-4.

7 D Solove, 'A Taxonomy of Privacy' (2005-6) 154 U Pa L Rev 477, 489.

${ }^{8}$ R Gavison, 'Privacy and the Limits of the Law' (1980) 89 Yale Law Journal 421, 423: 'in perfect privacy no one has any information about $\mathrm{X}$, no one pays attention to $\mathrm{X}$, and no one has physical access to X....' ibid, 428.

${ }^{9}$ A Westin, Privacy and Freedom (Atheneum 1967) 7.
} 


\section{THE PARADIGMATIC FRAMEWORK}

Traditionally viewed, privacy is important for individuals while free speech has wider, social functions. It is well established and unassailable that my privacy is of enormous benefit and value to me. Historically, privacy has been seen as being about harm to dignity, dating back to the original legal articulation in the late 1800s by Warren and Brandeis ${ }^{10}$, and to autonomy: dignity because publishing stories about my private life treats me as a means (to the publisher's profits and its readers' enjoyment) not as an end in myself - and autonomy, since it removes my right either to choose to release information about myself or to retain control such that information that I had not chosen to release or information over which I had asserted control (or over which I had limited the release, in terms of audience or details) becomes known. We see this realised in Campbell, with Lord Hoffman asserting that 'what human rights law has done is to identify private information as something worth protecting as an aspect of human autonomy and dignity. ${ }^{11}$ Lord Nicholls put it like this: a 'proper degree of privacy is essential for the wellbeing and development of an individual. ${ }^{12}$ Protecting privacy also assists us in maintaining our self-esteem and securing personal dominium. ${ }^{13}$ In his dissent in Wood, Laws LJ speaks of individual's personal autonomy making him 'master of all those facts about his own identity such as name, health, ethnicity, his own image. ${ }^{14}$

While this connotes privacy as something both intrinsically and instrumentally valuable $^{15}$ - in that protecting privacy allows us to flourish and feel better about ourselves knowing we have the sanctuary of secrecy - none of this conceives of private information as something in which you or anyone else would and should properly have any interest. Indeed, in their analysis of Warren and Brandeis's

\footnotetext{
${ }^{10}$ S Warren \& L Brandeis, 'The Right to Privacy' (1890) 4 Harv L Rev 193.

${ }^{11}$ Campbell v MGN [2004] UKHL 22, [2004] 2 AC 457 [50].

12 Ibid [12].

13 Ibid [56] (Lord Hoffman).

${ }^{14}$ Wood v Commissioner of Police for the Metropolis [2009] EWCA Civ 414, [2009] 4 All ER 951 [21].

${ }^{15} \mathrm{We}$ might even consider those non-consequentialist justifications as being both individual or collectivist - the latter that they speak to shared human traits, such as empathy or in the JudeoChristian tradition 'Judge not, that ye be not judged' (Matthew 7:1).
} 
articulation, Neil Richards and Daniel Solove make that very point. 'Their central phrase to describe the right to privacy--the right to be let alone--emphasizes the isolated individual and her ability to shut out invaders. ${ }^{16}$ The contrast with free speech is immediately and obviously instructive. Most obvious in this context would be the role that it plays within a political democracy - aiding the development of an informed electorate and self-governing citizenry, the view advanced by Alexander Meiklejohn ${ }^{17}$, or acting as a brake on power. ${ }^{18}$ This idea of truth as disinfectant best reflects the fictional urging of politicians to wear The Circle's SeeChange device. Alternatively, freedom of expression might bring about the social good of (better) truth in the market place of ideas. As Justice Holmes put it in his dissent in Abrams 'the best test of truth is the power of the thought to get itself accepted in the competition of the market. ${ }^{19}$ Free speech might also be imbued with the quality of 'social glue', drawing on Joseph Raz's idea about the validating function of public portrayals of lifestyles. ${ }^{20}$ They not only 'serve to reassure those whose ways of life are being portrayed that they are not alone' but 'they serve to familiarize the public at large with ways of life common in certain segments of the public'. Such portrayals, made real by the guarantee of free speech, thus serve a social function, that of community cohesion, perhaps not dissimilar to Lee Bollinger's notion of free speech inculcating reciprocal tolerance. $^{21}$

Each is now simply accepted judicially and theoretically as orthodoxy justification for the claim that free speech does indeed promote social harmony or does lead to falsity being hounded out of the market is never sought. Constructed thus - if privacy is something 'simply' of value only to me, as the means to effect my autonomy and guarantee my dignity - one does not have to be a utilitarian to recognise the difficulty that faces anyone seeking to prevent the media claiming

\footnotetext{
${ }^{16}$ N Richards and D Solove, 'Privacy's Other Path: Recovering The Law Of Confidentiality' (2007) 96 Geo LJ 123, 173.

${ }^{17}$ A Meiklejohn, Political Freedom: The Constitutional Powers of the People (HarperCollins 1960).

${ }^{18}$ Free speech 'is a safety valve: people are more ready to accept decisions that go against them if they can in principle seek to influence them. It acts as a brake on the abuse of power by public officials. It facilitates the exposure of errors in the governance and administration of justice of the country' $R v$ Secretary of State for the Home Department ex p Simms [2000] 2 AC 115, 126 (Lord Steyn).

${ }^{19}$ Abrams v United States (1919) 250 US 616, 630.

${ }^{20}$ J Raz, 'Free Expression and Personal Identification' (1991) 0JLS 303, 311.

${ }^{21}$ L Bollinger, The Tolerant Society: Freedom of Speech and Extremist Speech in America (OUP 1988).
} 
to be entitled to publish material about them. If however, we reconfigure privacy as something valued for its social utility - for the role it may play more widely, for the enhancements and benefits it can offer each of us collectively - then the relationship alters dramatically. It is to that we now turn.

\section{THE SOCIAL UTILITY OF PRIVACY}

This part of the article both draws on earlier theoretical accounts, bringing them together and developing them, and provides further rationales to demonstrate that we each of us have - or potentially have - a mutual interest in one another's private information. It does so by offering a new typology. It also seeks to situate those earlier analyses, which - and especially recently - have generally been located in discussions about a different aspect of privacy, that of freedom from surveillance. This part places those insights within a framework that relates to privacy against media intrusion. When, in this piece, there is talk of privacy or of privacy being protected, this is at an abstracted general level. It does not mean or does not assume - in doctrinal terms - that on any given facts, privacy has been and will be protected by, say, an injunction; in other words, that in the ultimate balancing test, Article 8 has come out on top over Article 10.

Within that, we can identify at least two different types of the wider social interest. The first is where $B$ (and maybe $C$ and $D$ ) - that is a minor, identifiable class has a parasitic interest in the privacy of $A$, to whom they have some connection, but which is an interest that is different from A's individual autonomy- or dignitybased interest in her own privacy. The other is where we all can be said to have a mutual interest in A's privacy - though again A's interests and ours are founded on different rationales. An example of the former is the point made in Campbell by Lord Carswell when he asserted that it was not simply the model herself who stood to gain from continued secrecy of the location of the Narcotics Anonymous meetings \& the details of the treatment. Publication might 'inhibit other persons attending the course from staying with it, when they might be concerned that their 
participation might become public knowledge. ${ }^{22}$ Similarly, in ETK there was discussion of the gains for the children of those in the public eye not being exposed to playground ridicule. ${ }^{23}$ While those examples provide some support for a wider conception of privacy, this article maintains that they are different from and lesser than - any general interest that unconcerned, disinterested citizens have in my continued privacy. It is those latter that will provide the surer footing for a social conception of privacy. It is those wider justifications that are our focus.

A number of different social conceptions of privacy will be discussed below. Not every one has the same obvious and immediate underpinning to the archetype factual matrix in a MOPI claim. For several - such as those termed meritocratic privacy or insulating privacy - the relationship with a classic MOPI claim is reasonably clear. At first sight though, for several more the relationship seems more tenuous. It is harder to see how, for example, what I term cohesive privacy, which we turn to first, can play a role in a media intrusion case. However, if we conceive of a MOPI claim as not solely being about preventing disclosure of moral or legal wrongdoing - even though many obviously are - but also having the objective of evading unwanted and unsought attention - and cases such as DMK, Mills, Weller, T $v$ BBC, Murray and GreenCorns all fit that latter mould - it becomes much easier to see how each of the various dozen or so conceptions might support that. ${ }^{24}$

While all the various rationales outlined below serve instrumental functions, we might better typify them as working at one of two meta-levels: effecting assurance or protecting activity. ${ }^{25}$ We mean by the former that the very act of protecting A's privacy per se has social significance, irrespective of whatever it is that $A$ is said to have done. There is a gain for $X Y$ and $Z$ etc simply from knowing that A's privacy in the abstract is or will be protected. Alternatively, social utility might accrue precisely because A's conduct - the specific details of what she has done

\footnotetext{
22 Campbell (n11) at [165].

${ }^{23}$ ETK $v$ NewsGroup Ltd [2011] EWCA Civ 439, [2011] WLR 1827 [17].

24 This point came up in private correspondence with Paul Wragg and made me think much more clearly about what it is I am laying claim to.

25 This idea was generated by thinking about the divide between class and contents in public interest immunity claims.
} 
or said - remains private to her alone. This is what is meant by protecting activity as being socially valuable.

\section{Effecting assurance as social utility}

Perhaps at its simplest, if your privacy is protected, that tells me that mine will be. If yours is not, why should I suppose that mine will be? More widely, if your privacy is protected, that tells me that we both live in a rights-protecting society, and that we each, and all, of us has a stake in that shared endeavour. Privacy rules thus act as socio-political signifiers, offering us all the collective security of the individualised focus of a liberal democracy. ${ }^{26}$ In doing so, they evince a commitment to cohesive privacy. This is something we can derive from Robert Post's analysis. Rules on privacy guarantee socially appropriate behaviour, vouchsafing 'the forms of respect that [we are] entitled to receive from others...[and] safeguarding rules of civility and the chain of ceremony'. ${ }^{27}$ Publication of private material is then a form of collective attack on those shared norms. Indeed, as he notes, we cannot see a MOPI action as seeking to maintain the secrecy of private facts - since it cannot and does not. We are better to understand it 'as a means of obtaining vindication for the infringement of information preserves [that means the claimant] is ultimately reintegrated into that chain of ceremony which defines and embraces members of the community'. ${ }^{28}$ Rules that mean we are unable to pry into our neighbour's affairs - literal or figurative - in one sense are thus both the cost, as well as the benefit, of one form of political organisation. In Rawlsian terms, we might see rules that guarantee privacy as the price we pay to reduce the strains of commitment, something that encourages us all to 'buy' into the social contract. ${ }^{29}$ We might term this co-optive privacy.

\footnotetext{
26 This has echoes of much wider debates in human rights discourse about the collective or social role of individual rights: I'm grateful to Michael Hamilton for that observation.

${ }^{27}$ R Post, 'The social foundations of privacy: community and self in the common law tort' (1989) 77 Cal L Rev 957, 967-968.

${ }^{28}$ Ibid, 986.

${ }^{29}$ J Rawls, A Theory of Justice (Belknap Press 1971).
} 
A guarantee of privacy simpliciter - that is, aside from any shroud it offers to the private activity - performs a normative structuralising function, what we might consider to be norm-inculcating privacy. Rules assuring us that our privacy will be protected very clearly set out public limitations on the actions of third parties, whether governmental and other private actors. The very act of hiving off aspects of one's existence - and denoting them as private, as beyond the reach of any other - is itself thus a socially significant act. This is the sense in which Priscilla Regan sees privacy. ${ }^{30}$ For Paul Schwartz, the delineation of (informational) spheres and thus of aspects of our lives in turn leads to the creation of very clear public and private domains, with the former essential to the political. ${ }^{31}$ The notion that life comprises different spheres of operation is meaningful in and of itself. Of course, the ideological construction of a liberal secluded space is very much, or can very much be seen, as contestable. It might not be well known but there is no formal guarantee of privacy in the African Charter on Human and Peoples' Rights (the Banjul Charter) of 1981 - though, as its name suggests, includes various collective rights, in Articles 19-24 - perhaps reflecting the (South) African notion of ubuntu, common or shared humanity. ${ }^{32}$ Indeed, arguing for privacy to have a particular politically normative utility does not predict - and is not necessarily predicated on - a particular certain organising social form. We shall see below that we might conceive of privacy creating what Fried calls the 'necessary atmosphere, 33 for trust to flourish and thus capable of founding reciprocal relationships at the heart of a more collective form of political organisation. It is an irony perhaps that protecting individual privacy might furnish stronger collective ties.

It is then but a small step to thinking about constitutive privacy, the idea put forward by both Paul Schwartz and Julie Cohen that a guarantee of individual

\footnotetext{
${ }^{30}$ Regan (n2) 221-230.

${ }^{31}$ P Schwarz, 'Privacy and Democracy in Cyberspace' (1999) 52 Vand L Rev 1609 ('Privacy and Democracy').

32 Similarly, the emergence of a cultural concept of privacy in China is only a recent development: The Economist, 'The long march to privacy', 12 January 2006 (available here http://www.economist.com/node/5389362) which piece starts it is surely telling that the characters that make up yinsi, the Chinese word for 'privacy', carry the connotations of illicit secrets and selfish, conspiratorial behaviour.' The suggestion is that attitudes toward privacy were shaped largely by traditional living arrangements. I am grateful to Karen McCullagh for this.

${ }^{33}$ C Fried, 'Privacy' (1968) 77 Yale LJ 475, 478.
} 
privacy provides the foundations for a mutual (and reflexive) shaping of society and its underlying values. ${ }^{34}$ How might it do so? Schwartz explains. A proper 'democracy requires more than group deliberation at a town square located either in Real Space or in cyberspace. It requires individuals with an underlying capacity to form and act on their notions of the good in deciding how to live their lives. ${ }^{35}$ That, in turn, requires 'boundaries about personal information to help the individual and define terms of life within the community'. ${ }^{36}$ We need to live our lives in both the private and public sphere, with symbiosis between the two. In the private, hived-off realm, we construct our notion of the good life - and then seek to give effect to it in the public realm...as of course does everyone else. Struggling to realise those aspirations, what Julie Cohen termed 'critical citizenship' - in communion with some, in opposition to others - gives necessary vitality to the public sphere, avoiding what she terms a 'modulated democracy'. ${ }^{37}$ In a similar vein, Ruth Gavison has written how, in fostering autonomy, privacy supports democratic self-government in that autonomous decision-making by citizens is a condition of such a political form. ${ }^{38}$ Priscilla Regan speaks of privacy as facilitating the creation of multiple personas (something we consider below). ${ }^{39}$ This in turn has a socially instrumental value. We place in the background and in private those aspects that separate us from others allowing us in the public, civic realm to foreground that which unites us - rather than being constantly driven apart by public differences - thus confirming our equal status as citizens. ${ }^{40}$

Another means by which privacy-protection rules provide a social surety function is one we might term meritocratic privacy - the assurance we all have, as I put it in an earlier piece, 'that those seeking appointment to public positions will not be deterred from putting themselves forward solely because of the fear the media

\footnotetext{
34 The idea of 'constitutive privacy' is raised in P Schwartz, 'Privacy and Democracy' (n31) 1658 and developed in P Schwartz, 'Internet Privacy and the State' (2000) 32 Conn L Rev 815 and in J Cohen, 'What is Privacy for?' (2013) 126 Harv L Rev 1904.

${ }^{35}$ Schwartz, 'Privacy and Democracy' (n31) 1654.

36 Ibid 1664.

${ }^{37}$ Cohen (n34).

${ }^{38}$ Gavison (n8) 455.

${ }^{39}$ Regan (n2).

40 Though as Julie Bailey notes, 'an account of privacy that valorizes it as a vehicle for social peace by concealing differences' is unlikely to be a long term vehicle for substantive equality, another valid social good: J Bailey, 'Towards an Equality-Enhancing Conception of Privacy' (2008) 31 Dalhousie LJ 267, 292.
} 
will hang out their dirty linen, their minor transgressions, daily on the front pages'. ${ }^{41}$ While there is a clear benefit to individuals who will not need to deny themselves opportunities simply because they do not feel 'better able to cope with life in the spotlight and the media glare or who [do not] feel that they have nothing to hide ${ }^{42}$, there is a clear public or collective interest. ${ }^{43}$ It cannot be a positive thing to place political, sporting, cultural, and business appointments out of reach of those who have disqualified themselves on grounds of previous indiscretion or, in the case of someone like Lord Browne, because they would prefer not to open aspects of their private life to scrutiny. ${ }^{44}$ We are all able to take comfort from the fact that appointments and promotions are deserved and given, all things being equal, to the best candidates.

\section{Protecting activity as social utility}

While the protection of privacy per se is capable of effecting several useful social benefits, the fact that privacy protection rules shroud specific conduct is also able to serve a host of wider socially instrumental functions.

First, let us consider Neil Richards' ideas about intellectual privacy, developed in the context of surveillance, both state and from powerful private actors such as Google and Facebook. ${ }^{45}$ He has argued that privacy and free speech are not in opposition; instead we should view their relationship as symbiotic and supportive. Privacy - that is insulation from surveillance - is needed to shield our intellectual activities and our thinking from public gaze. Freedom to speak implies we have something worth saying - so we need time in private to marshal and develop our thoughts. Richards provides us with only a starting block. While he does not

\footnotetext{
${ }^{41}$ D Mead, 'It's a funny old game - privacy, football and the public interest' [2006] EHRLR 531, 550.

42 Ibid.

${ }^{43}$ Looked at in purely economic terms, the allocative efficiency of this might go some way towards stemming the supposed distributive inequalities identified by Lior Strahilewitz that flow from the more privacy-protective European environment benefitting 'elites at the expense of the masses': see L Strahilewitz, 'Towards a Positive Theory of Privacy Law' (2013) 126 Harv L Rev 2010, 2015 et seq. Two consequences are said to flow: 'First, authorized celebrity gossip will form a higher percentage of published celebrity 'news.' Second, elites will retain privileged access to true information about celebrities via their social networks.' (ibid, 2017).

${ }^{44}$ Lord Browne of Madingley v Associated Newspapers Ltd [2007] EWCA Civ 295, [2008] 1 QB 103.

${ }^{45} \mathrm{~N}$ Richards, 'Intellectual Privacy' (2008) 87 Texas Law Review 387 and Intellectual Privacy (OUP 2015).
} 
explicitly seek to construct a social model of privacy along lines being developed here - that is, that we all gain from A's privacy being protected - it is probably safe to assume it is implied: 'If we are interested in a free and robust public debate we must safeguard its wellspring of private intellectual activity. ${ }^{46}$ The public gains to freedom of speech that spring from individual privacy are recognised. There is recognition of this in domestic case-law. In John Terry, Tugendhat $\mathrm{J}$ made that same point: 'Article 8 even promoted freedom of speech as well as of conduct since speech can only be conducted freely if the parties are in private. ${ }^{47}$ Where Richards' argument is more suspect is his exclusive focus on what we might best typify as internal cognitive privacy. ${ }^{48}$ Indeed the type of MOPI claims that are our concern are, in his view, outwith the need for amplified protection:

To be sure, some kinds of privacy claims-like the paradigmatic Warren and Brandeis claim against the press based upon hurt feelings - do threaten First Amendment values, in this case the need to protect the institution of the press so that it can provide information of public concern. ${ }^{49}$

That may well be true but is far too narrow a formulation. There are two points to make. Whilst it is hard to imagine a case where, if the press is prevented from publishing private information (or even, simply, seeking to gather it), that could not be said to have constrained (in US terms) the First Amendment rights of the press, does it follow then that public discourse more widely is impoverished? As we shall see, being able to protect private information from public disclosure allows individual flourishing to which we can quite properly attribute speech gains, either through wider or 'better' speech. One would be Richards' own case that ideas are properly thought through before being expressed. Another would be the idea that anonymity - on the internet but we could think of it more generally - allows us to hear views from certain marginalised or insecure groups otherwise denied us: whistleblowers and victims of abuse would be two that spring to mind. Secondly,

\footnotetext{
46 Richards, 'Intellectual Privacy' (2008) (n45), 391.

${ }^{47}$ John Terry (formerly LNS) v Persons Unknown [2010] EWHC 119 (QB) [98].

${ }^{48}$ He refers to 'cognitive processes': Richards, 'Intellectual Privacy' (2008) (n45) 391.

49 Ibid, 407.
} 
even if it we were to accept the case that privacy against media intrusion reduces our collective enjoyment of freedom of expression by limiting freedom of the press, that does not mean that preventing the public disclosure of private information cannot make more secure or more effective the exercise of other rights by others. We might term this facilitative privacy. Privacy not only allows each of us individually, and then collectively, fuller exercise of the rights of free speech and of thoughts and belief (if we accept the first counter above), but it also allows a fuller exercise of the rights to assemble and associate - and thus aids political plurality. One such means is that by privileging private communications, it facilitates unorthodox groups in organising. ${ }^{50}$ Further, by affording us the right to retain control over our private information, it can assist in securing rights of equal treatment by shrouding (certain) personal characteristics, publication of which - or in Rawlsian terms, lifting the veil of ignorance - might mean we suffer discrimination or differential treatment. ${ }^{51}$

Closely linked to this is another socially-valuable outcome: innovative privacy, privacy here acting as the guarantor of, as Julie Cohen saw it, the freedom to tinker. $^{52}$

\begin{abstract}
Privacy shelters dynamic, emergent subjectivity from the efforts of commercial and government actors to render individuals and communities fixed, transparent, and predictable. ${ }^{53}$
\end{abstract}

We need here to think of the work of Ruth Gavison ${ }^{54}$, and also of Edmund Kitch's prospect theory in relation to intellectual property. ${ }^{55} \mathrm{It}$ is not simply free speech that might be facilitated by an effective guarantee of privacy but experimentation,

\footnotetext{
50 On which see E Paton Simpson "Privacy and the Reasonable Paranoid: the Protection of Privacy in Public Spaces" 50 (2000) U Toronto LJ 305, 342 and also J Bohman, 'Expanding dialogue: The Internet, the Public Sphere and prospects for Transnational Democracy' in N Crossley and J M Roberts (eds), After Habermas: New Perspectives on the Public Sphere (Blackwell, 2004) 138. I'm grateful to Val Swain for making me aware of this latter work.

51 The rejoinder is that it does not in fact do so, but instead achieves false equality based on a public lie. True equality requires equal treatment despite public disclosures.

52 Cohen (n34) 1920.

53 Ibid 1905.

${ }^{54}$ Gavison (n8).

55 On this, see B Choi, 'A prospect theory of privacy' (2015) 51 Idaho Law Review 623 which I found enormously helpful.
} 
human flourishing and social progress more widely and generally: privacy as catalytic, the 'sponsor and guardian to the creative and subversive'. ${ }^{56}$ The opportunity cost of allowing premature access to our ideas and thoughts is that they do not ever become fully fledged. Exposure leads to reticence - 'public failures make us unlikely to try again. ${ }^{57}$ The social, collective gain from others achieving their best - whether that be Steve Jobs or Lionel Messi - must be undeniable. As Gavison puts it, 'I doubt that we could have many great pianists if individuals could practice only under the scrutiny of their not-always-sympathetic peers'. ${ }^{58}$ There are also clear links to what we earlier termed constitutive privacy. The dissonance and diversity that privacy protection is capable of heralding are essential conditions for socio-political change, advance and improvement:

\begin{abstract}
Liberal democratic citizenship requires a certain amount of discomfort - enough to motivate citizens to pursue improvements in the realization of political and social ideals. The modulated citizenry lacks the wherewithal and perhaps even the desire to practice this sort of citizenship. ${ }^{59}$
\end{abstract}

Nearly fifty years ago, Charles Fried spoke of the moral capital that privacy creates. It is this that allows us to engage in what Valerie Steeves and Priscilla Regan have called 'social negotiations' ${ }^{60}$ Privacy avails us of both the choice and opportunity to 'shar[e] information about one's actions, beliefs, or emotions which one does not share with all'. ${ }^{61}$ In doing so, it generates trust between individuals, the bedrock for 'entering into the relations of voluntary reciprocal forbearance for mutual advantage'. ${ }^{62}$ There are echoes here of what we earlier termed co-optive privacy, but in this case situated not at the social macro level but at the micro level, and with a focus not on privacy as assurance but on privacy as protecting certain conduct. By allowing us to choose what items or information to make

\footnotetext{
56 T Macklem, Independence of Mind (OUP 2007) 36.

57 Gavison (n8) 448.

58 Ibid 461.

${ }^{59}$ Cohen (n34), 1918 and see too H Nissenbaum, Privacy in Context: Technology, Policy, and the Integrity of Social Life (Stanford University Press 2009) 77.

$60 \mathrm{~V}$ Steeves and P Regan, 'Young People online and the social value of privacy' (2014) 12 Journal of Information, Communication and Ethics in Society 298, 304.

${ }^{61}$ Fried (n33).

62 Ibid 481.
} 
public, and on what terms and to whom, privacy creates a form of currency something which we might exchange with others to allow entry to different social groups, thus to kick-start and oil the wheels of shared endeavour. ${ }^{63}$ We might conceive of this as socialising privacy. David Feldman proposed that privacy helps foster 'mutually dependent ...purposeful co-operative activity' ${ }^{4}$ by controlling 'access to social groupings to enable the participants to engage in communal activities which they regard as valuable'. ${ }^{65}$ Viewed in reverse, when free speech claims are used to legitimise publication to the world of certain material about us - material we would choose to keep to ourselves or would choose to release only to selected known friends - this compromises our ability to form social networks that are more expansive. The risk of embarrassment that comes from some minor youthful indiscretion or momentary lapse becoming more widely known save to those trusted few who already know may well prevent us making new friends or developing new relationships. Jane Bailey put it thus: such releases 'might even be argued, in some cases, to interfere with the individual's ability to form relationships because of the rush to judgment that might occur as a result .... ${ }^{66}$ This brings in our earlier point about internet anonymity. Writing in the late 1940s, American sociologists William Moore and Melvin Tumin proposed the social value of ignorance. One insight chimes well here:

\begin{abstract}
Even the security of the individual may depend upon ignorance by others of personal attributes or past experiences that have no intrinsic bearing on his present status but which would be regarded unfavorably if known: for example, the technical Negro who is passing for white, the reformed ex-convict, the person below or
\end{abstract}

\footnotetext{
63 On this though, see the contrary view expressed by Tugendhat J in Goodwin $v$ NGN; NGN $v$ VBN [2011] EWHC 1437 (QB) [97] 'The first thing that people generally want to know about one another is the relationships of each other with one another and with other people. Each person wants to know whether there is any common relationship, or any relationship which might preclude, or limit, the development or continuation of the relationship between the two of them. The most important information about an acquaintance or colleague is: are they friend or foe, trustworthy or untrustworthy, and what relationship each can form or develop with the other (in the broadest sense of those terms).'

${ }^{64}$ D Feldman, 'Privacy-related Rights and their Social Value' in P Birks (ed), Privacy and Loyalty (Clarendon Press 1997) 22.

65 Ibid 24.

${ }^{66}$ Bailey (n40) 279 albeit in a very different context, that of the privacy claims of those featured in child pornography.
} 
above the required age for his position, the illegitimate child subsequently adopted. ${ }^{67}$

The social benefit of A's individual privacy in such a case is predicated on personal identity being something that is not inscribed and static but socially contextualised and reflexively interactive. I learn about myself from my interactions with others. A learns to develop, to mature and to change following those interactions - as in turn does B: 'identity is formed through direct and mediated interaction with others'. ${ }^{68}$ Thus, there is a shared interest in socialisation, something that a guarantee of limited release of information can help bring about. Of course, these exchanges of information - and the trust that flows - are not uniform. Privacy allows us to keep control of certain information from $B$, less from $C$, while allowing $D$ to know an entirely different set of information about us. As James Rachels noted, these varied informational exchanges allow us to create differentiated relationships with others, as well as allowing us to confer different public statuses on ourselves: husband, employee, friend, football fan, school governor. ${ }^{69}$ This heterogeneity in turn has clear social utility in a liberal society, linked to the promotion of the good life. The downside, of course, is that deception is sanctioned - and that too comes at a social cost. We might make foolish judgements of others based on incomplete or partial information and there is a clear social value in such assessments being fully informed and thus reliable. If such be true, Neil Richards's argument above that informational privacy might erode (meaningful) free speech and public discourse is made stronger.

We considered above the normative role that a guarantee of privacy simpliciter might play in the social sphere, first constructing a distinction between the

\footnotetext{
67 W Moore and M Tumin, 'Some Social Functions of Ignorance' (1949) 14 Am Soc Review 787, 790. On one aspect of that, see the recent exposure of white Caucasian woman Rachel Dolezale, leader of the NAACP in Washington State, who had lived and identified for many years as black: R Péñrez-Peña, 'Black or White? Woman's Story Stirs Up a Furor' The New York Times 12 June 2015 www.nytimes.com/2015/06/13/us/rachel-dolezal-naacp-president-accused-of-lying-about-herrace.html access on 17 January 2017.

680 Gandy, 'Exploring Identity and Identification in Cyberspace' 14 (2000) Notre Dame J L Ethics and Pub Pol'y 1083, 1089 and generally A Giddens, Modernity and Self-Identity: Self and Society in the Late Modern Age (Stanford University Press 1994).

${ }^{69}$ J Rachels, 'Why Privacy is Important' (1975) 4 Philosophy and Public Affairs 323, 326.
} 
personal and the public/political ${ }^{70}$ and then indicating where it might be sited. Where the protection that is offered shrouds specific private activities - such that we remain in control of which ones we choose to make public - then we can conceive of a further normative role for privacy-protection: norm-reinforcing privacy. The label of privacy is conferred on what are considered to be socially legitimate conduct and behaviours. ${ }^{71}$ Privacy protection rules therefore minimise the publicity given to deviance, 'reinforcing the assumption that deviation from the rules is statistically insignificant ${ }^{72}$, thus, the argument proceeds, reducing our individual propensity to deviance. There is a clear wider instrumentalism. Socialisation, and the strengthening of communal ties, is supported through what Moore and Tumin term the 'induction of subservience' of individual to group interests. ${ }^{73}$ While there is, it must be true, considerable social value in the production and reproduction of conformity, there is too social benefit from dissent. Neither per se is 'good'. Cass Sunstein summed it up well:

I do not suggest that dissent is always helpful. Certainly we do not need to encourage would-be dissenters who are speaking nonsense. The honor roll of famous dissenters includes Galileo, Martin Luther, Thomas Jefferson, Elizabeth Cady Stanton, Gandhi and Martin Luther King Jr. But there is a dishonour roll of dissenters too including many of history's monsters, such as Hitler, Lenin, defenders of American slavery, and Osama bin Laden. So defined, dissent cannot possibly be celebrated as such. Sometimes dissenters lead people in wrong directions. ${ }^{74}$

That is made worse, as he explains later, by social cascading of conformity and by group polarisation whereby those with similar views reach or take more exacerbated positions, through reinforcement.

\footnotetext{
70 Though this is without offering a view on the legitimacy of such a divide.

${ }^{71}$ A Westin, 'Social and Political Dimensions of Privacy' (2003) 59 J Soc Issues 431, 433 and see also W Warren \& B Laslett, 'Privacy and secrecy: a conceptual comparison' (1977) 33 J Soc Issues 43, 44.

72 Moore and Tumin (n67) 791.

73 Ibid

${ }^{74}$ C Sunstein, Why Societies Need Dissent (Harvard University Press 2003) 7.
} 
All this in turn posits a tension with one of the social functions of privacy that we identified earlier, innovative privacy. On one hand, the argument being made here is that privacy is 'good' because it reduces perceptions of deviance (and thus, it is argued, reduces deviance). Moore and Tumin put it well: 'Traditional behavior depends in part upon ignorance of alternative. ${ }^{75}$ On the other, it was argued earlier that privacy is 'good' because it promotes deviance, the lifeblood of social change. ${ }^{76}$ The tension might be resolved if we consider privacy to comprise both external and internal manifestations. What is not being suggested here is that blanket obedience to social norms is per se and always of social benefit, though often and selectively it will be (though nothing in this paper is offering judgement one way or another on specific norms). Its assertion is narrower. It is that privacy can contribute to both norm-reinforcement and norm-countering, each of which has the potential to be socially valuable. ${ }^{77}$ The tension appears to be put well through Daniel Solove's observation about the sodomy laws in Georgian England. ${ }^{78}$ Instead of sowing the seeds for countering social norms, privacy rules in fact might operate in reverse. Privacy can (and indeed in his example, did) cloak norm-deviation, stunting social change. The development of blackmail laws in the $17^{\text {th }}$ century - as he puts it, another means of securing privacy - is attributed to the need to deal with the growing number of people seeking to profit from their homosexual relationship with someone of social standing. The solution was not to repeal the law outlawing sodomy. On the specifics, he perhaps overplays his hand: there is probably little doubt that laws that prevent $A$ from extorting money from $B$ on pain of threat of revelation play a socially valuable role. Which has the greater social utility - that or equalising the law on sexual relationships - is an ethical question, of course. Gay men have been blackmailed in the UK since 1967 when the law was changed - so the legality of homosexual activity, rather than its (perceived) morality and acceptability might be less of an

\footnotetext{
75 Moore and Tumin (n67) 791.

76 This is part of what Janis Goldie termed 'expressive privacy' - protecting 'people from the overreaching social control of others that would inhibit self-expression and freedom of association ...[and] from the pressures to conform to socially accepted viewpoints or practices': J Goldie, 'Virtual Communities and the Social Dimension of Privacy' (2006) 3 U Ottawa L \& Tech J 133, 139. She considers it primarily as of value for an individual, and only socially and instrumentally valuable as laying the foundation for the ability to build social relations and thus for reflexive self-identity, an aspect of what is termed above socialising privacy.

77 A point also made by Cass Sunstein - but one which he takes no further: Sunstein (n74) 157-8.

78 D Solove, Understanding Privacy (Harvard University Press 2008) 95-96.
} 
issue. Be that as it may, there is no doubt that some of the wider social effects of protecting individual privacy might not be gains, or there might be some ambivalence about their true social value.

It is this internal/external distinction that explains the role Jed Rubenfeld attributes to privacy, that of mitigating against 'insidious, thought-numbing standardization'. ${ }^{79}$ Julie Cohen praises the 'behavioural variability' that she claims is engendered but this is far likelier to be internal or contemplative rather than active and external. Without public 'role' models - the point we identified with Joseph Raz earlier - the norm-reinforcing, centripetal pull of privacy protection rules must be strong. That said, we can identify a further social value to privacy but not because it might have instrumental constitutive or dynamic value but more simply. This is the idea of eclectic privacy. We are surely likelier to live our lives more freely and to the full if we are guaranteed that whenever we do, this is not trumpeted from the rooftops by a newspaper? While that is an identifiable individual gain, there must also be a clear public interest in diversity and in heterogeneity. That we are able when we are younger to experiment - with ideas, with looks, with personas ${ }^{80}$ - is due to the security that individual privacy brings yet over time and aggregated this capacity for self-development brings about social gains too. This takes us to a further social value, drawing on Erving Goffman's ideas about back stage behaviour, where we can relax. ${ }^{81}$ This is the notion of insulating privacy. Affording us the security that comes from knowing that private matters will not be published acts as a safety valve, allowing us an existence away from public pressures and public performance - avoiding the suffocating effects, as Solove refers to it, of being on constant possible display. ${ }^{82}$ The compartmentalising that privacy brings means perfection is not always expected - we do not always have to be, or act or look our best. ${ }^{83}$ The relief this

\footnotetext{
${ }^{79} \mathrm{~J}$ Rubenfeld, “The right of privacy’ (1989) 102 Harv L Rev 737, 785.

80 There is considerable literature on the self-developmental aspects of privacy for teenagers in the context of on-line activity at least: see e.g. S Livingstone, 'Mediating the public/private boundary at home: Children's use of the internet for privacy and participation' (2005) 6 Journal of Media Practice 41 and P Regan and V Steeves above (n60).

${ }^{81}$ E Goffman, The Presentation of Self in Everyday Life (Doubleday Books 1959) 112.

82 D Solove, "I've Got Nothing To Hide" And Other Misunderstandings Of Privacy' (2007) 44 San Diego L. Rev. 745, 762.

83 If so, then the notion that anyone has any interest in how I look when I pop out for a pint of milk must be open to doubt; c.f. Baroness Hale in Campbell (n11) [154].
} 
ushers in allows each of us room and time to re-energise ourselves, something of clear value to us as individuals but with consequential social gains. Ruth Gavison wrote about how privacy 'ameliorates tensions between social preferences and social norms'. ${ }^{84}$ This again promotes that necessary social heterogeneity by allowing us the freedom of multi-personas without feeling pressurised to conform, but goes further. It removes the attendant strain and so reduces the risk of social anomie and all that that might entail. Stephen Margulis sums it up thus: privacy 'is posited to provide experiences that support normal psychological functioning, stable interpersonal relationships' ${ }^{35}$ There are other psycho-social gains from realising the protection of private information. It removes the potential for alienating disjuncture - not simply the idea that 'someone out there knows something about me,' as Colin Bennett phrased it ${ }^{86}$, but that everyone out there now knows something about me which I would prefer them not to have known.

We saw earlier, when we considered Solove's ideas about blackmail, that protecting privacy might bring both social gains and social losses or at least there might be some ambivalence. This brings us to our last conceptualisation. To conclude this part of the article, we will turn now to another topic where, perhaps counter-intuitively, we might start to fashion a case for the social utility of privacy. Rather inelegantly we might convey this as coalescing privacy. This was to some degree informed by the discussion that surrounded the 'unmasking' of Italian author Elena Ferrante in 2016. ${ }^{87}$ Broadly, and in summary, this was that not only had she the right to privacy, to write anonymously, but that there was a wider interest - if not social, then of her many readers - to be able to continue reading her novels in ignorance of any personal details or backstory. This then is the idea that privacy-protection rules can contribute to public debate. First, the absence of any privileged knowledge, save that known to the person, creates a

\footnotetext{
${ }^{84}$ Gavison (n8) 452.

85 S Margulis, 'Privacy as a Social Issue and Behavioral Concept' (2003) 59 J Soc Issues 243, 246.

${ }^{86} \mathrm{C}$ Bennett, Regulating Privacy Data Protection and Public Policy in Europe and the United States (Cornell University Press 1992) 28.

${ }^{87} \mathrm{~L}$ Alexander, 'Why is the exposure of Elena causing such outrage?' BBC News on-line 5 October 2016 http://www.bbc.co.uk/news/magazine-37556183 access on 17 January 2017 and see generally J Mullan, Anonymity: A Secret History of English Literature (Princeton UP 2008). We might also think of the police officer writing as Nightjack: Author of a Blog v Times Newspapers [2009] EWHC 1358 QB.
} 
level field for debate. ${ }^{88}$ Secondly, it means that we are able to exercise judgement on policies and issues, not clouded by or affected by distracting publications of private information (though of course if $X$ remains a secret, we might all conjecture about 'hidden' facts $\mathrm{A}, \mathrm{B}$ and $\mathrm{C}$ as well as $\mathrm{X}$ !). ${ }^{89}$ Being able to conceal true matters from public gaze - while obviously of (considerable) individual benefit, would not seem to have any social value, quite the opposite. Indeed, Richard Posner has compared privacy in this regard 'to the efforts of sellers to conceal defects in their products', such as an applicant to join the police concealing a history of mental illness. ${ }^{90}$ However, there might be gains. Even if the private information published is true, we will be left with a picture that is incomplete and skewed. ${ }^{91}$ Full publication of every fact and detail about each of us is neither practically possible nor morally desirable. Protecting privacy might reduce the chance that any one and each of us collectively will mischaracterise anyone else. This does not really produce the sort of social value we have been thinking about so far - this is 'simply' aggregative rather than independently social. Yet, drawing on the work of Paul Schwartz, we might do so. ${ }^{92}$ Schwartz looked to Timur Kuran and his identification of preference falsification: where $A$ decides to present themselves as $X$ or to take view $Y$ based in turn on their falsely received understanding of some social phenomenon or fact. ${ }^{93}$ There is clearly a social gain from avoiding cumulative misconceptualisations and stereotyping - whether that be by government, business or others. Facilitating the forming of judgements and opinions and the basing of democratic discourse or public policy on partial, acontextualised information cannot be of benefit to any of

\footnotetext{
88 Though on this see Moore and Tumin (n67) 788 - that ignorance does the opposite: 'The function of ignorance that is most obvious, particularly to the cynical, is its role in preserving social differentials'. ${ }^{89}$ On which, Tugendhat J put this way in TSE $v$ NewsGroup [2011] EWHC 1308 (QB) [34] 'But there is another effect of NGN giving the details it did give about the Claimants. It thereby put the other individuals who fitted the description it gave in the article under suspicion and exposed them to the risk of intrusion into their private lives and harassment. This is a consequence of the way The Sun chose to report the proceedings. It need not have been a consequence of the claimants' action in bringing the proceedings.' In Goodwin (n63) he makes this observation: 'If a person does not wish to disclose an existing relationship, for whatever reason, there is a real risk that that will lead to misunderstanding or deception' ([99]).

${ }^{90}$ R Posner, 'The Uncertain Protection of Privacy by the Supreme Court' (1979) Sup Ct Rev 173, 174.

91 Though of course privacy protection does not guarantee impartiality in public portrayals about any of us - it simply allows us, rather than a third party, to determine the skew and incompleteness.

92 Schwartz "Internet Privacy" (n34) 840. The counter is that public debate is always enhanced by full disclosure about speakers' identity and background properly to allow listeners to reach an informed judgment on intention, for example.

93 T Kuran, Private Truth Public Lies (Harvard UP 1995) and see generally J Rosen, The Unwanted Gaze: The Destruction Of Privacy In America (Random House 2000).
} 
us. As Schwartz put it, a guarantee of privacy 'places restrictions on an 'outing' of knowledge and preferences that would be destructive to democratic community'. ${ }^{94}$ There is in fact a double whammy: not only does the absence of privacy protection encourage people to make false preferences but it favours certain (usually) elite groups who might be able to drive forward the publication and thus manipulate the agenda. Privacy protection minimises the opportunities for norm entrepreneurs - in our case, likely to be media institutions - from seeking improperly to shift the contours of public debate. ${ }^{95}$ All that said, whether or not it is of greater benefit to do so rather basing it on the absence of any information at all or only on information that we choose to release, the natural result of privacy-protecting laws, is clearly moot.

This part has identified that there are manifold ways in which it can be argued that protecting my personal privacy - specifically ensuring that information about me is not published - has instrumental value to others. We now turn to consider how far any of those wider social rationales have been played out in the case law before the domestic courts.

\section{THE ROLE AND PLACE OF 'THE SOCIAL' AND 'THE PUBLIC' IN PRIVACY DOCTRINE: AN EMPIRICAL STUDY}

In 'Internet Privacy and the State', Paul Schwartz offers the following insight on what earlier we termed the paradigmatic conception of privacy. It is one that

... conceives of privacy as a personal right to control the use of one's data. I refer to this idea as 'privacy-control.' This liberal autonomy principle seeks to place the individual at the center of decision-making about personal information use. Privacy-control seeks to achieve informational self-determination through individual stewardship of personal data, and by keeping information isolated from access. ${ }^{96}$

\footnotetext{
${ }^{94}$ Schwartz (n34) 843.

95 Ibid, 841.

${ }^{96}$ P Schwartz, 'Internet Privacy' (n34) 820.
} 
In this part, we shall consider how far that notion of privacy-control dominates judicial discourse and whether or not there is evidence of 'the public', in its various guises, playing out in the courts - and if so, to what extent - in decided MOPI cases.

A sample of the open judgments in 27 cases was selected. ${ }^{97}$ Westlaw listed 214 UK cases under the search term privacy /10 media decided between 1 January 1990 and 1 November 2016 (the date of the search), but only 45 if the search is narrowed to privacy /10 media /10 injunction. ${ }^{98}$ The former category includes cases that have nothing to do with MOPI injunctions against the press - such as (most recently at the time of writing) $D B \vee$ General Medical Council concerning disclosure of an expert report in professional practice hearing. ${ }^{99}$ The representative sample of $27(60 \%)$ is then of a sufficient size as to allow meaningful conclusions to be drawn. The cases were not selected entirely at random. It includes first instance hearings as well as both privacy cases to have

97 The cases were: $A v B \& C$ [2002] EWCA Civ 337, [2003] QB 195, AAA v Associated Newspapers Ltd [2013] EWCA Civ 554, [2013] WLR(D) 189, AMM v HXW [2010] EWHC 2457 (QB), Campbell v MGN [2004] UKHL 22, [2004] 2 AC 457, Carr v NewsGroup [2005] EWHC 971 (QB), CTB v NewsGroup [2011] EWHC 1232 (QB), Contostavlos v Mendahun [2012] EWHC 850 (QB), DMK v NewsGroup [2016] EWHC 1646 (QB), Douglas v Hello! [2005] EWCA Civ 595, [2006] QB 125, ETK v NewsGroup [2011] EWCA Civ 439, [2011] WLR 1827, Ferdinand v MGN Ltd [2011] EWHC 2454 (QB), Goodwin v NewsGroup [2011] EWHC 1437 (QB) (concerning the identity and position of Sir Fred Goodwin's lover at RBS), Green Corns v Claverly Ltd [2005] EWHC 958 (QB), Hutcheson (KGM) v NewsGroup [2011] EWCA Civ 808, JPH v XYZ [2015] EWHC 2871 (QB), Lord Browne of Madingley v Associated Newspapers Ltd [2007] EWCA Civ 295, [2008] 1 QB 103 and the High Court [2007] EWHC 202 (QB), McKenitt v Ash [2006] EWCA Civ 1714, [2008] QB 73, Mills v NewsGroup [2001] EWHC Ch 412, Murray $v$ Big Pictures [2008] EWCA Civ 446, [2009] Ch 481, PJS v NewsGroup [2016] EWCA Civ 393 and [2016] UKSC 26, [2016] AC 1081, Ntuli v Donald [2010] EWCA Civ 1276, [2011] 1 WLR 294, Rocknroll $v$ NewsGroup [2013] EWHC 24 (Ch), Spelman v Express [2012] EWHC 355 (QB), T v BBC [2007] EWHC 1683 (QB), John Terry (formerly LNS) v Persons Unknown [2010] EWHC 119 (QB), Theakston v MGN [2002] EWHC 137 (QB), Trimingham v Associated Newspapers Ltd [2012] EWHC 1296 (QB), TSE v NewsGroup [2011] EWHC 1308 (QB) and Weller v NewsGroup [2015] EWCA Civ 1176, [2016] 1 WLR 1541.

98 The decision to exclude the potential of Court of Protection cases was one that was taken deliberately although there is evidence of the wider competing interests playing out in doctrine: see for example $M v$ Press Association [2016] EWCOP 34 [34] where Hayden J said 'The challenge, in the parallel analysis of the competing rights and interests in play, is that the rights in contemplation are of wholly different complexion. The exercise involves the juxtaposition of the intensely personal (grief, loss, privacy) alongside the conceptual (the public interest, the freedom of the press, the effective dissemination of information, the administration of justice). In a jurisdiction where there is a human, and inevitable pull to the protection of the vulnerable, (this is after all the Court of Protection), it is easy to overlook how some of the wider, abstract concepts also protect society more generally and in doing so embrace the vulnerable.' I am grateful to David Acheson for making me aware of this judgment.

${ }^{99}$ [2016] EWHC 2331 (QB). 
reached the Supreme Court/House of Lords, Campbell and PJS, as well as appeals alongside looking at both first instance and appeal decisions in two, Murray and Lord Browne of Madingley. It ranges across interlocutory hearings and appeals - pre-publication to hearings for damages after the event. It covers cases from the early days of the Human Rights Act 1998, Theakston and $A \vee B$ \& $C$ (Gary Flitcroft), though the bulk are from about 2010. It therefore includes a few cases - including Mills - decided before $\operatorname{Re} S$ and the introduction of the new methodology recalibrating the balance between Articles 8 and 10. Several were chosen because the facts or individuals indicated a greater likelihood of judges addressing the wider social utility. Not all, though most, involved someone with a degree of fame or notoriety. Five were chosen at random from that Westlaw list: Carr, Mills, Spelman, $T \vee B B C$ and TSE.

The conclusions we can draw from that sample are that there is a near wholesale lack of judicial engagement with any underlying privacy or free speech or media theory - though that is probably not surprising. Do judges engage with theory in other areas of law... or indeed in other jurisdictions? Next, judicial accounts of possible rationales for protecting privacy are generally, indeed almost always, framed in individualistic terms. That said, some cases can be read or seen as even if not explicitly reasoned - as using MOPI to protect or to serve wider social goals. Last, the only time there is any consideration of the public element in privacy cases is on the other side of the coin - that of freedom of expression - at the stage of the intense focus and ultimate balancing test. There is simply no sense in which the social utility of privacy has any traction in judicial reasoning, and thus in outcomes of instant cases.

Examples of the individualistic conceptualisation of privacy abound, when we consider the sorts of harms that judges are keen to minimise or insulate against, or the good that judges seek to bring about. In Campbell, we read of the fact that protecting privacy serves to preserve personal autonomy, as well as obviating distress and the sense of betrayal. ${ }^{100}$ There are also the therapeutic gains to

100 Campbell (n97) [50] and [35] respectively. 
Campbell herself. ${ }^{101}$ There was emotional and financial damage from disclosure at heart in $\mathrm{JPH},{ }^{102}$ as well as the massive affront to dignity in $T \vee B B C$, the planned film of the last meeting between a vulnerable 18 year-old mother with an IQ of 63 (and unable to give informed consent to the filming) and her baby before the latter was taken for adoption. ${ }^{103}$ Other general, personal health concerns feature in $D M K^{104}$ and yet more strongly the very real 'danger of serious physical and psychological harm' in Carr, where Maxine Carr was seeking to restrain publication of any post-release personal details after serving her sentence for her role in two gruesome murders of young teenage girls. ${ }^{105}$ The driver to save or reduce embarrassment and upset, alongside security and safety concerns were to the fore in Weller ${ }^{106}$ and saving the children from a playground ordeal and bullying in ETK. ${ }^{107}$ Protecting an individual's fair trial rights was effected in DMK by the refusal to allow publication of information or identity when there was a separate ongoing Chancery action against her former lover. ${ }^{108}$ Several cases have averred to the benefit that privacy brings in allowing us ordinary social interaction without also having to expect to see it reported in the press the next day. ${ }^{109}$ Last there is the whole sub-category of intimate relations and protecting sexual choice such as Ferdinand ${ }^{110}$, Goodwin and Lord Browne but not it seems sexual status or sexuality or even sexual stereotyping or information on the quality of sex that one has (Trimingham ${ }^{111}$ ) or indeed very fleeting or transitory sexual relationships (Theakston ${ }^{112}$ ). The courts have even protected information derived from or conduct relating to the commercial sphere, provided it can be said to meet the requirements of reasonable expectation of privacy. ${ }^{113}$

\footnotetext{
101 Ibid [95], [119] and [145].

$102 \mathrm{JPH}$ (n97) [8].

${ }_{103} T$ v $B B C$ (n97) [16].

${ }^{104} \operatorname{DMK}(\mathrm{n} 97)[11]$.

${ }^{105}$ Carr (n97) [4].

106 Weller (n97) [37] and [65].

${ }^{107}$ ETK (n97) [17].

${ }^{108}$ DMK (n97) [11].

${ }^{109}$ In Lord Browne (n97) (High Court) [59] and Rocknroll (n97) [12] and Murray (n97)(Court of Appeal) [55].

110 Ferdinand (n97) [56].

111 Trimingham (n97).

112 Theakston (n97).

${ }^{113}$ Lord Browne (n97) High Court [33] - [42].
} 
Even where on the facts, protecting privacy might be seen to have wider social utility, these are rarely if ever adverted to. For example, there is not only a personal individual interest in having a fair trial - DMK - but a collective, social one, one that adverts (at very least) back to the idea of co-optive privacy that we identified earlier. If your privacy, or fair trial rights, is protected, that tells me that mine will be. It also has echoes of more socially constitutive concerns, that a fair trial is the bedrock of a society under the rule of law. In none of the countless privacy-of-relationships cases in the study was there even a nod to what we earlier termed co-operative privacy, that identified the functional role privacy plays in allowing us to establish and maintain social interaction, and thus flourishing both individual and collective. The only instance of judicial recognition of any wider attributes comes in Campbell when Baroness Hale locates her discussion of the social gains from protecting the confidentiality of therapeutic treatment in the context of the Strasbourg judgment in $Z v$ Finland. ${ }^{114}$ As she puts it,

\begin{abstract}
Respecting the confidentiality of health data is ...crucial not only to respect the sense of privacy of a patient but also to preserve his or her confidence in the medical profession and in the health services in general. Without such protection, those in need of medical assistance may be deterred from revealing such information of a personal and intimate nature as may be necessary in order to receive appropriate treatment and, even, from seeking such assistance, thereby endangering their own health and, in the case of transmissible diseases, that of the community. ${ }^{115}$
\end{abstract}

Similarly, in Spelman - the young sports player who also happened to be the son of a (then) cabinet minister, there is a sense of an impending judicial discussion of what we earlier termed innovative privacy - specifically the need to practice, so

\footnotetext{
${ }^{114}$ Z v Finland [1998] 25 EHRR 371.

115 Campbell (n97)[145]. As just one example, in the context of HIV, Leary \& Schreindorfer have documented the link between A's perception of likely stigmatisation at the release of his HIV status and A revealing details of that status to others including potential partners: $M$ Leary \& L Schreindorfer, 'The stigmatization of HIV and AIDS: Rubbing salt in the wound' in V Derlega \& A Barbee (eds), HIV \& social interaction (Sage 1998).
} 
as to improve, away from the media spotlight - but any adverting to wider social utility is foreclosed; it is very clearly framed in terms of individual benefit:

Participants in public sports and performing arts... reach the highest level by ascending from the lower levels. The restriction on what might otherwise be a reasonable expectation of privacy may well apply to those who aim for the highest level, even if they do not achieve it, or can no longer expect to achieve it. ${ }^{116}$

By contrast, judicial explanations of the rationales for protecting free speech framed in both individual and social terms are many and several. We might highlight this one, again by Baroness Hale in Campbell:

There are undoubtedly different types of speech, just as there are different types of private information, some of which are more deserving of protection in a democratic society than others. Top of the list is political speech. The free exchange of information and ideas on matters relevant to the organisation of the economic, social and political life of the country is crucial to any democracy. Without this, it can scarcely be called a democracy at all. This includes revealing information about public figures, especially those in elective office, which would otherwise be private but is relevant to their participation in public life. Intellectual and educational speech and expression are also important in a democracy, not least because they enable the development of individuals' potential to play a full part in society and in our democratic life. Artistic speech and expression is important for similar reasons, in fostering both individual originality and creativity and the free-thinking and dynamic society we so much value. No doubt there are other kinds of speech and expression for which similar claims can be made. ${ }^{117}$ 
While explicit judicial recognition of any of the various conceptualisations of privacy-protection as having social value or utility that we considered in Part IV was broadly non-existent in our study of 27 decisions, some cases can be read as using MOPI to protect or to serve more specific (but more narrowly tailored) social goals, even if they were not so clearly reasoned. ${ }^{118}$ Both $A M M v H X W$ and CTB give considerable weight to the wider social interest in preventing and punishing blackmail (a matter also relevant in the granting of anonymity orders) ${ }^{119}$ and the most obvious and sensible way to view JPH $\vee X Y Z$ is as preventing revenge porn. In Green Corns, there was a 'strong public interest' in the provision of secure care homes for troubled teenagers whether by the state or privately ${ }^{120}$ justifying the ban on a local paper printing the likely location of where new ones would be sited. We might also note that judgment reflects the social interest - in capitalist society - in commercial organisations being able to make a profit. Judges do appear to have taken contrasting views of such an objective. We might here think of the reasoning in John Terry case. There, Tugendhat $\mathrm{J}$ made clear that 'the real basis for [Terry's] concern.... is likely to be the impact of any adverse publicity upon the business of earning sponsorship and similar income.'121 Another theme that runs through several cases relates to the stability of family life, for example in ETK $v$ NewsGroup, alongside marriage reconciliation, and in Rocknroll maintaining and establishing caring relationships between children and (step) parents. ${ }^{122}$ Both Murray and Weller, while locating the right in the hands of the children themselves - on the facts, the young children of a famous parents can be considered as acknowledging the wider and longer term social importance of appropriate child development. Lastly, Carr can be seen as providing (physical) security thus promoting rehabilitation of former prisoners after release - again, a

\footnotetext{
118 I'm indebted to Paul Wragg for this observation and initial assistance.

119 Though compare SKA \& PLM v CRH [2012] EWHC 766 (QB) a case where an alleged blackmailer sought to disclose a businessman's adultery with, and impregnation, of $\mathrm{X}$ where no injunction was granted. Tugendhat J concluded that it could not be said that this disclosure about the claimant (not a public figure so far as one can tell) should not be enjoined because, even if the defendant were a blackmailer, to do so would deprive him of his Art 10 rights: "to tell a grown up child that his or her father ... is, or is about to be, the father of twins, is speech of a high order of importance' ([79]).

120 Green Corns (n97) [95].

121 Terry (n97) [95].

122 RocknRoll (n97) [36].
} 
socially valuable aim being pursued through (here) a contra mundum injunction. ${ }^{123}$

Perhaps the closest we ever get to an iteration of a more socialised function for the protection of individual privacy is the recognition of a 'zone of interaction' with others which we see in Strasbourg cases such as von Hannover No. $1^{124}$ and Sciacca ${ }^{125}$, and which has percolated into domestic law in Kinloch, JR38 and Wood. ${ }^{126}$ 'Article 8 is primarily intended to ensure the development without outside interference of the personality of each individual in his relations with other human beings.' Clearly, this chimes with the socialising conceptualisation of privacy that we outlined earlier ( $p$ ??) but does not go so far as to locate it within the social. It is very much portrayed as being of individual benefit rather than as your privacy being something in which I too might have a stake. There are echoes too perhaps of a more communitarian, Etzionian reading ${ }^{127}$, one that also takes issue with historic individualised focus of privacy but from a different perspective and one that reaches an alternative outcome. Individual privacy as currently conceived exempts certain acts from communal, governmental and public scrutiny, and thus privacy privileges individualism over shared or communal conceptions of the common good. This though still situates privacy as an individual right, but one that each or many of us has - rather than seeing it as one where I gain from your exercise of the right. It thus remains antagonistic with the public sphere, or as Solove puts it, an 'individual indulgence at the expense of society' - pitted against the common good rather than being part and parcel of it. $^{128}$

It will unlikely surprise many but the only time there is any consideration of the wider social or public value being contested in any privacy claim comes on the other side of the coin - that of freedom of expression - at the intense focus and

\footnotetext{
${ }^{123} \operatorname{Carr}(\mathrm{n} 97)$.

${ }^{124}$ von Hannover v Germany [2005] 40 EHRR 1 [50].

125 Sciacca v Italy (2006) 43 EHRR 400 [29].

126 Kinloch v HM Advocate [2012] UKSC 62, [2013] 2 AC 93 [19], In Re JR38 [2015] UKSC 42, [2016] AC 1131 [100], Wood v MPC (n14)[21].

${ }^{127}$ See A Etzioni, 'A Communitarian Perspective on Privacy' (2000) 32 Conn L Rev 897 and generally

The Limits of Privacy (Basic Books 1999).

${ }^{128}$ D Solove, Understanding Privacy (Harvard University Press 2008) 90.
} 
ultimate balancing test. This will be well known to readers of this journal. In Campbell for example Lord Hope speaks of 'the fundamental right to freedom of expression which the press assert on behalf of the public. ${ }^{129}$ The broadcasting function of the press has judicial pedigree. It was key in the speech of Lord Bingham in McCartan Turkington Breen (on qualified privilege ${ }^{130}$ ) and in GreenCorns, one of our study of 27 privacy cases, we are informed that 'the principle is that the public's need to receive information is, and can only be, met through the medium of the press.' 131 The judgment of Tugendhat $\mathrm{J}$ in John Terry even includes a heading 'The Social Utility of the Threatened Speech'. ${ }^{132}$

Familiar tropes here include whether or not there was a public interest in publication? What contribution will the publication make to a debate of public interest? In Ferdinand, Nicol J puts it this way

\begin{abstract}
Freedom of expression applies to banal and trivial expression as well as matters of public interest, but where that right has to be balanced against the rights of others to protect their privacy, the extent to which the content is of public interest or contributes to a debate of general interest assumes a much greater importance. Indeed, the contribution which the publication makes to a debate of general interest is the decisive factor in deciding where the balance falls between Article 8 and Article $10 .^{133}$
\end{abstract}

In Carr, for example, Eady $\mathrm{J}$ highlights two issues of legitimate public interest: the cost to the public purse of protecting and rehabilitating such a prisoner as Maxine Carr on release and any future lessons for child protection. However, as he continued, there was no need for her current whereabouts or her identity to be revealed for that debate to take place. ${ }^{134}$ Tugendhat $\mathrm{J}$ in Goodwin identified the public interest in '|the extent to which men in positions of power benefit from that

\footnotetext{
${ }^{129}$ Campbell (n97) [115].

130 McCartan Turkington Breen v Times Newspapers [2000] UKHL 57, [2001] 2 AC 277.

131 GreenCorns (n97) [83].

132 John Terry (n97) between [96] and [97], and see similarly P Wragg, 'The benefits of privacyinvading expression' (2013) 64 NILQ 187.

133 Ferdinand (n97) [62].

${ }^{134} \operatorname{Carr}(\mathrm{n} 97)$ [7].
} 
power in forming relationships with sexual partners who are less senior within the same organisation'. ${ }^{135}$ There is also the judicial pre-eminence given to political 'public sphere' speech, exemplified in ETK where there was 'no political edge to the publication. The organisation of the economic, social and political life of the country, so crucial to democracy, is not enhanced by publication. The intellectual, artistic or personal development of members of society is not stunted by ignorance of the sexual frolics of figures known to the public. ${ }^{136}$

Another theme is the public watchdog role of the press: those with the 'greatest need for this constitutionally vital freedom [of freedom of expression] are the organs of the media. In the interests of our democratic society we - and that includes the judges - must ensure that the press is freely able to enquire, investigate and report on matters of public interest. ${ }^{, 137}$ From here, of course, it is but one small step to seeking to realise the public interest in the continued existence of a viable free press by limiting those encumbrances on its ability freely to report, and thus to achieve sales. Such thinking seems now to have a firm purchase. One of Lord Woolf's guidelines in $A v B \& C$ in the Court of Appeal asserted that the courts 'must not ignore the fact that if newspapers do not publish information which the public are interested in, there will be fewer newspapers published, which will not be in the public interest'. ${ }^{138}$ In Campbell Lord Hoffman acknowledges that 'we value the freedom of the press but the press is a commercial enterprise and can flourish only by selling newspapers. ${ }^{139}$ Most recently, in ETK, this was framed by Ward LJ thus:

To restrict publication simply to save the blushes of the famous, fame invariably being ephemeral, could have the wholly undesirable chilling effect on the necessary ability of publishers to sell their newspapers. We have to enable sales if we want to keep our newspapers. Unduly to fetter their freedom to report as editors judge

\footnotetext{
135 Goodwin (n97) [103].

136 ETK (n97) [21].

${ }^{137}$ ETK (n97) [13].

${ }^{138} A v B \& C$ (n97) [11](xii).

${ }^{139}$ Campbell (n97)[77]
} 
to be responsible is to undermine the pre-eminence of the deserved place of the press as a powerful pillar of democracy. ${ }^{140}$

We might here recall that Prosser attributed as a key factor in Samuel Warren's decision to co-author that seminal piece the press intrusion into the wedding of his daughter. ${ }^{141}$ The original complaint of Brandeis and Warren in 1890 was that gossip was no longer

the resource of the idle and of the vicious, but has become a trade, which is pursued with industry as well as effrontery.... In this, as in other branches of commerce, the supply creates the demand. Each crop of unseemly gossip, thus harvested, becomes the seed of more, and, in direct proportion to its circulation, results in the lowering of social standards and of morality. Even gossip apparently harmless, when widely and persistently circulated, is potent for evil. It both belittles and perverts. ${ }^{142}$

More recently, it was put thus by Gavin Phillipson:

if the courts are able, through development of effective privacy rights, to discourage newspapers from publishing the kind of intimate gossip with which both these cases were concerned, then the result may well be a greater concentration in the media upon serious stories, including discussion of matters of real political and social importance. ${ }^{143}$

\footnotetext{
${ }^{140}$ ETK (n97)[13] and see the acceptance by Dingemans J in the High Court (Weller $v$ Associated Newspapers Ltd [2014] EWHC 1163 (QB) [147]-[149]) of the Daily Mail's case that show business or celebrity stories were popular and 'generated revenue through digital advertising spend which was critical to Mail Online's commercial model. A profitable news website allowed for freedom in journalism.'

141 W Prosser, 'Privacy' (1960) 48 Calif L Rev 383.

142 Warren and Brandeis (n10) 196.

${ }^{143}$ G Phillipson 'Judicial reasoning in breach of confidence cases under the Human Rights Act: not taking privacy seriously?' (2003) EHRLR Supp (Special issue: privacy) 54, 66.
} 
Yet would this really be so? As Lior Strahilewitz phrased it, 'news and gossip are not close substitutes. If the courts were to shut down TMZ.com, its readers would not suddenly flock to the Boston Review. ${ }^{, 144}$

Judicial pronouncements illuminate yet further aspects of the public interest. The public interest in the freedom to criticise and generate debate on 'socially harmful' conduct' was noted by Tugendhat $\mathrm{J}$ in John Terry, and had led, he continued by way of illustrative example, to such recent social changes as the rules on insider dealing and proscribing art sales from archaeological sites. ${ }^{145}$ There is longstanding public interest in exposing hypocrisy or public being misled, that we see at the heart of Ferdinand or Campbell, and reflected in the PCC code. In Spelman, there is acceptance that the welfare of children and young people was a matter fit for public discussion, leading to the discharge of an injunction that had prevented publication of a story framed by the newspaper as being about the risks that those responsible for organising national and international sporting activities might have interests that conflicted with the welfare of the children involved $^{146}$ - specifically as it turned out, in relation to performance-enhancing drugs. In $T \vee B B C$, the public interest addressed was that of adoption and childcare, in the context (specifically) of young, vulnerable mothers of low intelligence. ${ }^{147}$ Two cases advert to wider commercial or regulatory concerns that might not have come to light had an injunction been granted. The High Court in Lord Browne recognised that maintaining the proper corporate role of the board and shareholders in holding directors accountable (here, for alleged misuse of BP's resources and manpower to support or assist his partner) was a legitimate social aim. In Goodwin, a legitimate interest in corporate governance, specifically a breach of the RBS Code of Conduct (on conflicts of interest at work) was raised - but then abandoned - by The Sun before the High Court, arguing for publication. We might even note, and in stark contrast to the thesis being

\footnotetext{
${ }^{144}$ L Strahilewitz, (n143) 2016.

${ }^{145}$ John Terry (n97)[100]-[104]. He made a similar point in Goodwin (n97)[133]: 'It is in the public interest that newspapers should be able to report upon cases which raise a question as to what should or should not be a standard in public life. The law, and standards in public life, must develop to meet changing needs. The public interest cannot be confined to exposing matters which are improper only by existing standards and laws, and not by standards as they ought to be, or which people can reasonably contend that they ought to be.'

${ }^{146}$ Spelman (n97) [107].

${ }_{147} T$ v $B B C$ (n97) [17].
} 
advocated in this article, the courts accepting the public interest in spurned lovers being able to exercise their personal autonomy and self-development by a telltale story. ${ }^{148}$

Other discussions of the public side of individual personal privacy traverse wellknown ground: was the information obtained in a public place, emphasising the historic spatial skew towards private life? Was the information already in the public domain? Was the subject a public figure? ${ }^{149}$ As to the first, the location is becoming less pivotal as the courts move towards conceptualising the essence of the activity as the greater factor, such as the family outing in public in Weller. ${ }^{150}$ We have seen too, a loosening of approach on the question of prior publication, as the courts have moved towards framing claims as intrusions, in a MOPI claim, than when claims were based on confidentiality. It is now possible to intrude onto privacy repeatedly such that the public domain is no longer the simple on/off switch it once was. We see this in cases such as PJS (in the Supreme Court), in Rocknroll and in GreenCorns. For example in the last named, the Court decided that republication of existing material was capable of having a significant effect especially if it involved the collation of information such as to make it in effect 'new' information (addresses of properties in Land Register together with what business was being carried meant new information about the likely use of the properties in relation to troubled children). ${ }^{151}$ We glean another insight into the possible lessening of existing publication in Ferdinand, where the Court was prepared to accept that earlier articles and interviews with the footballer did not constitute sufficient voluntary disclosure of this relationship as later to deny him a reasonable expectation of privacy. ${ }^{152}$ Goodwin provides an interesting example of the public figure debate. There, Tugendhat $J$ distinguished on the one hand

\footnotetext{
148 Ntuli v Donald (n97)[22]-[23].

${ }^{149}$ See for example in RocknRoll (n97)[14]-[15] the Court's rejection of the paper's claim that the claimant was a public figure, attributable solely through marriage to the actress Kate Winslet and to his connection to his uncle, Richard Branson, albeit that he was simply a middle manager in his uncle's private business.

${ }^{150}$ See Weller (n97)[61]: This was a 'private family outing. It could have been a family visit to a local park or to a public swimming pool. It happened to be an outing to the shops and to a café which was visible from the street. The essential point is that it was a family activity which belongs to that part of life which is protected by the broader right of personal autonomy recognised in the case law of the Strasbourg court...'

151 GreenCorns (n97)[81].

152 Ferdinand (n97)[58]-[59].
} 
celebrities and sports players from, as here, the 'Chief Executive of one the largest publicly quoted companies in the United Kingdom, doing business on a global scale. Whatever limits there may be to the legal concept of a public figure, or of a person carrying out official functions, in my judgment Sir Fred Goodwin came within the definition. ${ }^{153}$ Whereas, in the High Court's view, Ned RocknRoll did not come within the category, something the newspaper had claimed attributable solely through marriage to the actress Kate Winslet and his connection to his uncle, Richard Branson, albeit that he was simply a middle manager in his uncle's private business. ${ }^{154}$

\section{CONCLUSIONS}

Inevitably, there are further obstacles that would require surmounting were privacy law to develop along lines suggested above - acknowledging that the potential harm is not just to one, but to us all. ${ }^{155}$ This last part posits a few of those tensions and concerns, and offers some tentative solutions and concluding thoughts.

Why does all this matter? I think there are two reasons. The first is a conceptual one. If we are to have newspaper outings of, taking a recent example, MPs such as Keith Vaz, we should be sure the analytical framework is responsive to all the variables, not just to some or, as I would argue, to all of those on one side (freedom of expression) but only to a sample on the other. Secondly, at a practical level, it matters how cases are argued and resolved and who might claim the benefit of any remedy. Let us take those in turn.

At a conceptual level, if we conceive of privacy as offering wider social utility rather than simply as something of individual value, we can better appreciate that the judicial and policy approach - of private gain against public benefit of free speech - creates a false dichotomy. Ian Leigh and Lawrence Lustgarten wrote

\footnotetext{
153 Goodwin (n97)[103].

154 RocknRoll (n97)[14]-[15].

155 For greater expansion and explication, see D Solove, 'The Meaning and Value of Privacy' in Roessler and Mokrokinska (n3) 78-80.
} 
about the balance between rights and security in the 1980s and Daniel Solove adopted it in the more specific context of digital privacy and security nearly twenty years later. ${ }^{156}$ Rather than being in oppositional tension, protecting privacy may in fact sustain the same sorts of goals that securing protection for free speech might also serve. We see this most obviously when we considered claims to intellectual privacy, to innovative privacy and to facilitative privacy, but insulating privacy allows us to relax before immersing ourselves once more in the public sphere, while coalescing privacy, it was argued above, provides the level playing field necessary for public debate. Viewing the potential harm as connoting something more collective requires the construction of a very different utilitarian calculus. In short, and perhaps counter-intuitively, failing to see that on occasion securing an individual's privacy (that is, not allowing unrestrained publication about someone's private life) might not also lead to a flourishing, rather than a diminution, of free speech constitutes a category error. Privacy and free speech, or elements of each at least, can in fact be the same sides of the coin.

A couple of points flow from that new analytical approach. If privacy is no longer solely an individual but also a social or collective good, does this mean $A$ is or even should be able to waive it? As Jane Bailey put it, in the context of on-line privacy, especially those victims/subjects of child pornography

\begin{abstract}
if privacy is, or is becoming, a collective or public good, the weaknesses of policy solutions that establish a property right in personal information or that allow one to waive one's privacy rights also would become clear. If one individual or a group of individuals waives privacy rights, the level of privacy for all individuals decreases because the value of privacy decreases ${ }^{157}$
\end{abstract}

There are two limbs to this. If $A$ really is not bothered by any loss of privacy, what could found B, C and D's collective right to be aggrieved? In Part III, we considered the various social claims that can be made on their behalf. Broadly,

\footnotetext{
156 I Leigh and L Lustgarten, In From the Cold: National Security and Parliamentary Democracy (OUP 1994) and D Solove, Nothing to Hide: The False Tradeoff Between Privacy and Security (Yale UP 2011). 157 Bailey (n40) 293.
} 
even if $A$ feels she has suffered no harm, a strong case can be made that not only are $B, C$ and $D$ impoverished but we all are, or at least there is the potential for us all to be. Put thus, it is not A's right, or not A's right alone, to waive. That thought does not assist in resolving the other difficulty - how can we give practical effect to that collective assertion of harm, especially in the face of A's consent or intransigence? One practical response in the UK setting would be the adjustment of regulatory rules requiring only the affected individual to mount a claim. IPSO requires, for complaints about anything other than accuracy in the Editors' Code, a person to be 'directly affected'. IMPRESS similarly requires someone to have been personally affected other than for complaints about accuracy where it permits third party complaints. This provides, at best, only a very partial solution. It is one thing to confer standing on third parties and quite another to craft a remedy that adequately responds to those collective, mutual interests. ${ }^{158}$ The following (rather inelegantly drafted) sample correction avails a flavour of that might be conveyed ${ }^{159}$

On 1 January, we published an item indicating that $A$ had done $X$ [in circumstances Y]. While A did not contact us to complain, The Daily News acknowledges that in publishing that item, we acted improperly. That item might have led many others to believe that doing $X$ [in circumstances $Y$ ] was a proper subject for a newspaper to report on. In doing so, we may have dissuaded others from doing or even from trying to do $\mathrm{X}$. The Daily News accepts that doing $\mathrm{X}$ is or has the potential to be a socially useful activity, contributing to $[\beta$ and $\delta^{160}$ ] and thus has long term or wider benefits for us all.

Remaining with our conceptual strand, James Nehf identifies two further issues that flow from framing privacy as implicating only individualised utility. First, those not affected, or rather those perceiving themselves as not being affected, may disengage from the debate. This is, as Solove points out, a general response in

\footnotetext{
${ }^{158}$ I am grateful to the reviewer for raising this. I confess I do not have an adequate response. 159 It is premised and thus worded to reflect the socially valuable instrumentality of protecting specific activities. A differently worded construction would be needed to reflect the idea of privacy as effecting assurance.

${ }^{160} \beta$ and $\delta$ would correspond to some or all of the various socially beneficially outcomes in Part III, such as innovation, norm-reinforcement or eclecticism.
} 
the surveillance and security debate - l've got nothing to hide, so what's the problem? ${ }^{161}$ Additionally, and this flows from its non-absolute nature requiring privacy to compete with other rights and social interests, he notes that 'the influence of interest group politics could not be overcome. ${ }^{162} \mathrm{He}$ adverts to the changed frame within which we now debate environmental harms - as something that now no longer effects simply the neighbour onto whose land waste spills but as a general societal problem calling for a public collective regulatory response. $^{163}$

If we turn back to the practical realisation of our expanded notion of privacy, Part IV showed that there was no evidence of wider social utility in court judgments (though the survey has not so far considered how cases were presented and argued by counsel). It is impossible to determine if appeals to social utility would have affected the outcome in any one case. It would be easy enough to locate claims to a more socially responsive conception of privacy within the current doctrinal framework. Even given the very clear contextual steer in Murray by the Master of the Rolls ${ }^{164}$ (and endorsed by the Supreme Court in In re JR $38^{165}$ ), the first stage, - whether or not there was a reasonable expectation - while objective, has as its focus the effect on the claimant, not the effect on wider society. Nothing though would seem to prevent it being argued at the second stage of the ultimate balancing test that it is not simply the comparative importance to the claimant that should be on one side of the equation but the social good that protecting privacy could effect or would be capable of effecting.

While the appropriateness of the balancing test is contested at a normative level, primarily because of the difficulty, indeed inherent impossibility, of attributing value to and then weighing against each other two things that are both immeasurable and incommensurable, this paper takes as a given its continued traction. ${ }^{166}$ This is not the place to rehearse, let alone resolve that argument.

\footnotetext{
161 Solove Nothing to Hide (n156).

162 J Nehf, 'Recognizing the societal value in information privacy' (2003) 78 Wash L Rev 1, 72-73

163 Ibid 74.

164 Murray (n97) [36]

165 In re JR 38 (n126) [88] (Lord Toulson).

166 On which, as one recent example, see P Wragg, 'Protecting private information of public interest:
} 
That said, while re-framing privacy, in collective terms, would complicate that balancing exercise, by pairing public interest expression with of public interest privacy, we might explore this a little more before ending. ${ }^{167}$ While, clearly, it would be impossible to prove or even quantify the social utility of preventing a particular privacy-invading publication, that should not matter. The claim that a free press contributes to democratic self-governance has never been put to proof; its truth has now simply been asserted so long and so vociferously that it is selfevident - judicial notice is simply taken of this now undisputed fact. ${ }^{168}$ Further, it is not being asserted that all invasions of A's privacy would implicate a more collective notion of privacy. This though is, or should be true, for free speech (on the other side of the equation) - not all speech goes to enhancing democracy or offering different versions of truth in the market place for acceptance or rejection; it is hard to see how tittle tattle can ever do so. ${ }^{169}$ Our more socialised conception of privacy entails rejection of the monolithicism of free speech and, now, of privacy and calls for a more nuanced judicial analysis of both sides, evaluating more precisely the exact harms alleged to be suffered if the material is (not) published. Of course, to repeat the point made above, what we dealing with on the privacy side is more likely an inchoate harm but this is likely as true of many claims made about the collective harms, or gains, of free speech.

In all this, it would be critical properly to frame the various interests at play and in tension. This might be the wider social utility or the countervailing public interest. Tugendhat $\mathrm{J}$ was alert to the difficulties in GreenCorns. ${ }^{170}$ There, the issue - to remind ourselves - was whether or not to restrain a local paper publishing certain details of a planned children's care home. He accepted that there was no public interest properly defined at all in publishing the information that was subject to restraint. ${ }^{171}$ The public interest was in how (perhaps by whom) the children were to be cared for. That was not the material the paper sought to publish, which was

\footnotetext{
Campbell's great promise, unfulfilled' (2016) 7 JML 225.

167 The discussion here was prompted by a reviewer comment, for which I am grateful.

${ }^{168}$ Although on this see the recent Court of Protection judgment of Charles J in Re C (Deceased) [2016]

EWCOP 21 especially [158]-[166]. Again, I'm grateful to David Acheson for this.

169 Though on which see P Wragg, 'The benefits of privacy-invading expression' (2013) 64 NILQ 187,

194.

${ }^{170}$ GreenCorns (n97).

${ }^{171}$ Ibid [99].
} 
the location of the home. Essentially, what was being set up in opposition, he continued, was a series of private interests in, for example, house values which the paper sought to aggregate and to be wrapped up collectively as a public interest. $^{172}$

In conclusion, one matter should be made clear. This paper is not arguing that privacy should always or even invariably trump free speech: we should not always have a right to know about the love child of a leading politician. There will quite properly be times - many and frequent perhaps - as a matter both of plain doctrine and of policy and theory - when the interest in protecting someone's privacy is outweighed by the greater interest in publication, even where there might also be some consequent social or collective (future) loss if the private facts become publicly known. It is making the much simpler point. That it is time we reconceptualised privacy and its instrumental possibilities, and thus reconfigured the balancing matrix, avoiding (in footballing terms) free speech always being the team able to play at home. ${ }^{173}$

\footnotetext{
172 This goes to an earlier discussion: that there is a difference between a common or collective public interest, in Regan's terms (above $\mathrm{n}$ 2), and aggregative or cumulative private interests.

173 Mead (n41) 549.
} 